\title{
Professional Competence as a Key Factor in Improving the Quality of Engineering Education
}

\author{
Lesia Zbaravska \\ Department of Physics and Engineering \\ Discipline \\ State Agrarian and Engineering \\ University in Podillia \\ Kamianets-Podilskyi, Ukraine \\ olzbaravska@gmail.com
}

\author{
Sergii Slobodian \\ Department of Physics and Engineering \\ Discipline \\ State Agrarian and Engineering \\ University in Podillia \\ Kamianets-Podilskyi, Ukraine \\ dakgps@pdatu.edu.ua
}

\author{
Olha Chaikovska \\ Department of Social and Humanitarian \\ State Agrarian and Engineering \\ University in Podillia \\ Kamianets-Podilskyi, Ukraine \\ olgachaikovskaya@ukr.net
}

Oleksandr Dumanskyi

Department of Agricultural Machinery

and Mechanization Technology

State Agrarian and Engineering

University in Podillia

Kamianets-Podilskyi, Ukraine

dakgps@pdatu.edu.ua

\author{
Hutsol Taras \\ Vice Rector for Educational, Scientific \\ and Pedagogical Affairs \\ State Agrarian and Engineering \\ University in Podillia \\ Kamianets-Podilskyi, Ukraine \\ pro-gp@pdatu.edu.ua
}

\begin{abstract}
The integration of Ukraine into the European community is impossible without changes in the education sphere. The implementation of such projects of the European Union as "Horizon 2020" provides the collaboration between experts in Agriculture and Engineering. The results of the questionnaire conducted by "Agro Survey" agency showed the lack of student's practical knowledge in Ukrainian Engineering and Agricultural universities. It is obvious that the quality of education in Ukrainian technical universities doesn't meet the requirements of the European labour market. Getting theoretical knowledge has no value until students can apply it for practical purposes. We suggest that a subject like Physics should be practice-oriented. If the Physics course at technical universities integrates theory with practice, students will be better prepared for their future career.
\end{abstract}

The purpose of the study is to define the basic principles of professional competence as the key factor for improving the quality of future engineer's training in the process of studying Physics.

To select and interpret the factual material, concepts and theories the theoretical analysis of philosophical, psychological and pedagogical literature on research was used in the paper. The pedagogical experiment was carried out on the basis of 4 universities in different regions of Ukraine and involved 159 respondents (151 students and 8 university teachers). To determine the strategies for implementation of the profession-based tasks in Physics course we carried out specially designed questionnaires for students majoring in Agrarian Engineering and university teachers.

One of the necessary conditions for future engineer training is professional orientation in studying. We suppose that to consider the relationship between a comprehensive

Physics course and the disciplines of professional and practical training the in-depth analysis should be performed. First of all, it will help to determine Physics knowledge, abilities and skills that should be used in student's further professional training. Second of all, it will enable the most effective use of engineering-based tasks in Physics classes. However, knowledge of basic Engineering and General Theoretical subjects is not applied by the students of Technical High School for a long-period of university study. The results of the survey have shown that studying major subjects at a later stage doesn't motivate students to learn Natural Science and Engineering disciplines.

We can conclude that profession-based tasks in Physics class contribute to the formation of a system of natural knowledge, practical skills and abilities. They stimulate the students' cognitive interest in Physics as a science, help to better absorb material of other disciplines, develop creative abilities and influence the formation of persistent motifs for obtaining knowledge of professional disciplines.

Keywords - professional competence, practice-oriented, Physics, professional training, agrarian engineering.

\section{INTRODUCTION}

High School is a background to the future of most students. Yet many students finish universities unprepared for a career. Professional competence training of graduates should be one of the priorities in Higher Education that provides a perfect final result, i.e. an expert who has mastered the necessary knowledge, abilities, has higher order of creative skills, the appropriate worldview and erudition, intellectual level, who acquired the skills of self-study and formed the professional qualities and moral, aesthetic, ecological culture. Consequently, the 
development of the professional competence model for High School is one of the most urgent issues today.

The academics examined the characteristics of specialist professional training in international affairs [16], medicine [1], the border guard servicing [18] on the basis of an interdisciplinary approach [13], [14]. Some studies on the professional competence training, its basic principles and the impact on the career of a future engineer [15] [2], [4], [5], [9], have been done by Ukrainian [3], [11], [12] and foreign academics [6], [7], [8], [10], [17]. However, there is a number of questions that was not discussed at all. Moreover, the research on the development of profession-based Physics teaching methods with the students of Agricultural and Technical High Schools is still lacking.

The review of regulatory literature, plans and curriculum, standards for engineering training, educational characteristics of experts in agriculture engineering allowed us to state that:

- there is a disagreement between the content of new standards of education and outdated teachingmethodological, instructive and normative support and pedagogical strategies;

- the principle of professional orientation in teaching Physics with the students of Agricultural and Technical Universities is not fully implemented;

- there is a tendency for student mastering a vast amount of educational material and for systematical reducing the hours for in-class studying Physics;

As a result, a significant number of students doesn't realize the goal of studying Physics. During the period of their learning, they don't fully acquire the basic knowledge in Physics and have no experience of its applying to perform the tasks associated with the future professional activity [12].

To develop the profession-based model for teaching Physics in High School the authors identified the following tasks: to determine the basic principles of professional competence and to identify the most effective professional competence strategies for preparing experts in engineering; to describe the specifics of implementing the vocational-oriented technologies in Physics for students majoring in agricultural engineering; to test the effectiveness of implementation of profession-based tasks in Physics course.

\section{MATERIALS AND METHODS}

The pedagogical experiment was aimed at testing the effectiveness of professional competence approach for the systematization of Physics course learning in Agricultural and Technical High School, at improving the content and forms of education, at developing means for intensification of the educational process and the complex of knowledge diagnostics.

The research was carried out on the basis of State Agrarian and Engineering University in Podillia, National University of Life and Environmental Sciences of Ukraine and Nizhyn Agrotechnical Institute. The study involved 151 students majoring in Agrarian Engineering. The pedagogical experiment also included the questionnaire for 8 lecturers who teach Physics for students majoring in Agrarian Engineering at Lviv National Agrarian
University and State Agrarian and Engineering University in Podillia.

The experiment had the following stages:

- the organization of experimental and research training;

- the analysis of organizational, structural and contextual changes in the process of studying Physics and their influence on the level of student's knowledge in Agricultural and Technical High School;

- the evaluation of teaching activity. Physics teachers who participated in the pedagogical experiment followed the original Physics guides, recommendations and other educational and teaching materials in their teaching practice.

A testing system for learning achievements that performed diagnostic, control, motivational and educational functions was designed in the process of pedagogical experiment. The pedagogical monitoring was carried out on the basis of standard tools (tests, reference works, surveys, etc.). We should admit, it was simple, convenient and effective. On the one hand, the pedagogical control determined the level of students' progress in Physics, and, on the other hand, the results of the monitoring showed the effectiveness of discipline teaching and studying.

During the pedagogical experiment the following methods were used:

- the observation of the educational process and the analysis of Physics and Engineering disciplines teaching methods during attending the classes;

- $\quad$ the questionnaire and the interview.

\section{RESULTS AND DISCUSSION}

The observation showed low student participation in the Physics classroom, the absence of motivation and interest in the training material, low grades.

The questionnaires contained several survey questions focused on expressing the idea according to certain supposition.

The following questions were used in the survey:

1. What is the role of Physics in your future profession?

2. Does Physics lay the groundwork for studying the professional disciplines?

3. What is the role of Physics in completing professional tasks?

4. Does Physics help you to write a Diploma Thesis?

5. Does Physics help to improve your intellectual potential?

6. Does Physics help to form logical thinking?

7. Does Physics help to form creative thinking?

8. Does Physics assist the training of agrarian engineer?

9. Is it possible to do profession-based teaching and research work without the knowledge and skills in Physics?

Almost $95 \%$ of the students stated that Physics in Agricultural and Technical University doesn't influence 
the study of professional disciplines. More than $60 \%$ of the respondents associate Physics with such Engineering disciplines as "Electronics", "Theoretical mechanics", "Machine Parts". However, the students agree that "Theory of Mechanisms and Machinery», «Mechanics of Materials and Structures" have no relationship to Physics.

The exam grades in professional disciplines showed that the students don't use the issues and the laws of Physics in the process of studying the disciplines of professional and practical training. What is more, about $87 \%$ of the students don't associate Physics with the disciplines of professional and practical training.

The student's answers to the question "What should be done to increase the level of student professional training in the process of studying Physics" were the following:

- to improve the financial and logistical support of the educational process (the percentage index of all interviewed students is $15.2 \%$, where $19.3 \%$ of students are from National University of Life and Environmental Sciences of Ukraine, 3.7\% of students are from Nizhyn Agrotechnical Institute and 6.7\% of students are from State Agrarian and Engineering University in Podillia.

- To improve teaching methodology of Physics (the percentage index of all interviewed students is $23.85 \%$, where $15.6 \%$ of students are from National University of Life and Environmental Sciences of Ukraine, $48.2 \%$ of students are from Nizhyn Agrotechnical Institute and $40 \%$ are students from State Agrarian and Engineering University in Podillia;

- to provide profession-based tasks in different types of training activities in Physics (the percentage index of all interviewed students is $21,9 \%$, where $25.7 \%$ of students are from National University of Life and Environmental Sciences of Ukraine, $11.1 \%$ of students are from Nizhyn Agrotechnical Institute and 13.3\% are students from State Agrarian and Engineering University in Podillia);

- To increase the hours for Physics classes (the percentage index of all interviewed students is $17.9 \%$, where $16.5 \%$ of students are from National University of Life and Environmental Sciences of Ukraine, $25.9 \%$ of students are from Nizhyn Agrotechnical Institute and $13.3 \%$ are students from State Agrarian and Engineering University in Podillia);

- To increase the level of teacher professional training (the percentage index of all interviewed students is $13.9 \%$, where $13.8 \%$ of students are from National University of Life and Environmental Sciences of Ukraine, $11.1 \%$ of students are from Nizhyn Agrotechnical Institute and $20 \%$ of students are from State Agrarian and Engineering University in Podillia);

- to create the conditions for the development of students' ability to self-study (the percentage index of all interviewed students is $3.3 \%$, where $3.7 \%$ of students are from National University of Life and Environmental Sciences of Ukraine, $6.7 \%$ of students are from State Agrarian and Engineering University in Podillia and no respondents have chosen this variant of answer in Nizhyn Agrotechnical Institute);

- Six students have offered their own answer: the implementation of new information technologies in studying the profession-based material.

Physics teachers had to determine the strategies for the implementation of profession-based principle in the educational and methodical supply of Physics course. The results of teachers' survev auestions are shown in Fig. 1.

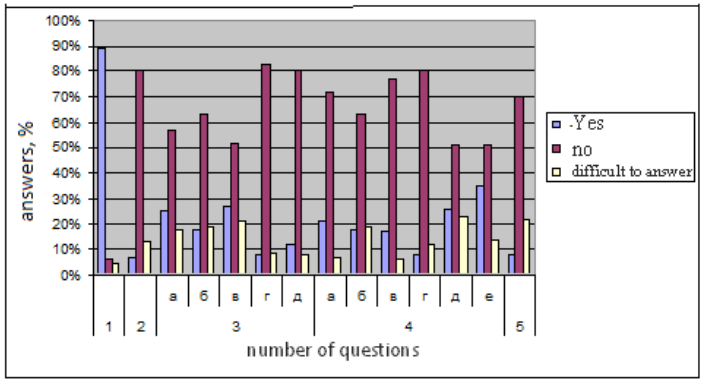

Fig. 1. The diagram of teachers' questionnaire results

More than $50 \%$ of the teachers answered that Physics course content is not connected with the future engineering specialization of students. In addition, teaching Physics with the students of Agricultural and Technical Universities doesn't differ from the content of the Physics course in Technical High School, except the number of curriculum hours.

The teachers-respondents confirm that laboratory workshops in Physics and practical training are not related to the future profession. Teachers of professional disciplines highlight that students don't have the skills to apply Physics knowledge in disciplines of professional and practical training.

The obtained results make it possible to confirm that:

- the majority of students doesn't experience the close relationship between Physics, General Technical disciplines and disciplines of professional and practical training;

- the content of the lectures and practical classes sometimes contains abstract material and laboratory classes don't differ from Physics classes at Pedagogical Universities.

The analysis of the research results proves the fact that Physics curriculum in Ukrainian Technical High Schools doesn't integrate disciplines of professional and practical training. The traditional system of teaching Physics in Agricultural and Technical Universities doesn't benefit from the implementation of professional orientation in teaching Physics and doesn't allow to significantly affect the professional development of the students.

\section{Conclusions}

To sum up, the use of interdisciplinary links and applied Physics tasks in the educational process will allow forming the student's perceptual unity in Physics structure and content of Physics. The integration of Physics and profession-based disciplines will help students to realize the importance of Physics for their future career and to form the basic professional knowledge and skills.

The implementation of the gradation system of professional education in Ukraine determines the need for further research on the teaching strategies for the profession based learning in Agricultural and Engineering 
High Schools. It's very important to adopt the most appropriate scheme for implementation of professionbased learning. It will help to coordinate the teaching, to avoid the duplication of educational material, to reduce inefficient time costs, to provide future experts with deeper and stronger knowledge.

\section{REFERENCES}

[1.] A. El-Moamly, "Medical Education in the New Millennium". New York: Nova Science Publishers.

[2.] A.I. Hurev, "Status of interdisciplinary links in the system of modern education". Science and school, 2, 2002, pp.41-45.

[3.] A.V. Konysheva and E.N. Ibragimova, "Training of Engineers in Mathematics at University on the Basis of the Information Cybernetic Approach". EURASIA Journal of Mathematics, Science and Technology Education, 2017, v. 13, n. 8 , pp. $4379-4391$.

[4.] A.V. Hutorskoi, "Pedagogical Innovations: Methodology, Theory and Practice". Moskow: «UNZ DO» publishing house, 2005.

[5.] B.A. Ermeling and J. Yarbo, "Expanding instructional horizons: A case study of teacher team-outside expert partnership". Teachers Colleges Record, 2016, v.118(2), pp. $1-48$.

[6.] C.Lyall,A. Bruce, J.Taitand L. Meagher, "Interdisciplinary Research" Journeys: Practical Strategies for Capturing Creativity. London: Bloomsbury, 2011.

[7.] D. Kaittani, V. Derri, and E. Kioumourtzoglou, "Interdisciplinary: a focus on physics and physical education". Sports Science, 2016, n. 9, pp. 22-28.

[8.] F. King, "Teacher professional development to support teacher professional learning: Systemic factors from Irish case studies”. Teacher Development, 2016, v.20(4), pp. $574-594$.

[9.] H. Timperley, "Realizing the power of professional learning". London: McGraw-Hill Education, 2011.

[10.]L. Marcu, "Science education: the need for an interdisciplinary approach". Oradea University, 2007, v. XIV, pp. 53-56.

[11.]L. Zbaravska and S. Slobodyan, "Interdisciplinary communication in teaching physics for students of agricultural universities". Central European journal for science and research, Praha, 2016, pp. 97-101.
[12.]L. Zbaravska, I. Bendera, and S. Slobodyan, "Problem book in profession-based Physics". Kamianets-Podilskyi: PP Zvoleyko D.G., 2010.

[13.]M. Borrego and L. Newswander, "Definitions of interdisciplinary research, toward graduate-level interdisciplinary learning outcomes". The Review of Higher Education, 2010, v. 34(1), pp.61-84.

[14.]S. Aboelela, E. Larson, S. Bakken, O. Carrasquillo, A. Formicola, S. Glied, et al. "Defining Interdisciplinary Research: Conclusions from a Critical Review of the Literature". Health Research and Educational Trust, 2007, v.42(1), pp.329-346.

[15.] V.A. Bolotov, "The Competence Model: From an Idea to a Curriculum". Pedagogics, 10, 2003, p.8-14.

[16.] V. Tretko, "Interdisciplinary approach to teaching of Masters in international affairs". Adult education: theory, experience and practice Journal, 6 (13), 2013, pp.194-202

[17.]X. Cheng and L.-Y. Wu, "The affordances of teacher professional learning communities: A case study of a Chinese secondary school". Teaching and Teacher Education, 2016, v.58, pp. $54-67$.

[18.]Yu. Kuz, "Border guides training methodology in automated complexes and border control devices". Extended abstract of candidate's thesis. Khmelnitskyi: Khmelnitskyi National Academy of Border Guard Service, 2015.

[19.]L. Zbaravskaya, T. Hutsol, V. Melnyk, "Improvement of professional knowledge of students through the use of interdisciplinary connections and applied physical tasks" Bulletin of the Ukrainian Branch of the International Academy of Agrarian Education, 2014, pp. 230-237.

[20.]I. Bendera, L. Zbaravskaya, T. Hutsol, T. Dudar, "Professional orientation in the lecture course of physics for students in the direction of the preparation "Transport technologies"', Bulletin Sevastopol National Technical University. Series: Machinery and equipment and transport, 2011, pp. 133-137.

[21.]K. Dziedzic, K. Mudryk, T. Hutsol, B. Dziedzic; "Impact of grinding coconut shell and agglomeration pressure on quality parameters of briquette, Engineering for rural development", 2018, pp. 1884-1889.

[22.] T. Hutsol, N. Kosulina "Biophysical bases of radiometric receivers application for there mote diagnostics of the animals health situation", Bulletin of State Agrarian and Engineering University in Podilya, 2016, pp. 73-79. 